\title{
Power Sharing in Progressive Discipline: New Rules of Engagement Arising from an Australian Perspective
}

\author{
John Chelliah \\ University of Technology, Sydney \\ E-Mail: john.chelliah@uts.edu.au \\ Pitsis Tyrone \\ University of Technology, Sydney \\ E-Mail: tyrone.pitsis@uts.edu.au
}

\begin{abstract}
The aim of this exploratory study is to apply the lens of power to the understanding of progressive discipline in Australian workplace contexts. Using data from the Australian Industrial Relations Commission, we analysed the outcomes of 78 unfair dismissal cases across 17 industries over a four-year period (1997-2000). We found that the application of progressive discipline on employees is concentrated around industry and occupational class. Specifically, it shows that occupational classes such as unskilled, skilled, and sales staff are more susceptible to disciplining by employers. It raises the awareness of the immense power the employer derives from the use of progressive discipline over employees and implications in the new environment of on-going labour deregulation and the lack of statutory intervention to ameliorate the growing power imbalance.

Given that the research focuses on progressive discipline, the data provides strong grounding for theory building and telling a story on the industrial relations environment where power is becoming increasingly oriented towards employers, especially as union density declines. As such, we hope the simplicity of our research inspires further research that uses more advanced statistical analysis and modelling.

The paper has implications for managers/supervisors involved in formulation of progressive discipline policies and for employee advocates who champion employee welfare. It demonstrates that power determines employee performance outcomes, which may not necessarily be in the interest of the employer and to a greater degree the employee. When applying current theory in power, one can challenge the
\end{abstract}


relevance of archaic progressive discipline practices in the context of today's economic realities. We offer some insights into improving progressive discipline as a tool of managerial control. Our recommendations in this paper will also be relevant to countries with labour legislation and human resource practices similar to Australia such as U.S.A., United Kingdom, Canada, and New Zealand.

Keywords: Progressive Discipline, Power, Australian Arbitration, Governmentality

\section{INTRODUCTION}

This paper explores the forms of power employers wield under the guise of managerial control through progressive discipline. Progressive discipline refers to the process through which employers discipline employees for misconduct or unsatisfactory job performance at the workplace in an incremental way. The main aim of progressive discipline is to assist an employee with lifting performance by giving the feedback and support to correct the problems encountered. Termination of employment resulting from an employer's inadequate progressive discipline endeavours may be deemed an unfair dismissal under Australian federal legislation. The word "progressive" in this form of discipline denotes the fact that the penalties get progressively heavier as an employee continues not to meet the expectations of the employer, e.g. fails to attend regularly, fails to perform properly or fails to behave acceptably in accordance with company policy (Kleiner and Pesulima, 1999). The initial goal is to improve performance and not to punish the employee for his/her shortcomings. The employer's actions in carrying out progressive discipline could include oral and written warnings, suspensions, or probation, depending on the nature of the offences and policies of the employer (Kleiner and Dhanoa, 1998; White and Scott, 1984). However, after the employee is given a reasonable opportunity to improve his/her performance, if there is no progress, then the consequences become more serious and ultimately lead to termination (Martin, 1990).

At face value, the provisions relating to progressive discipline in the Australian context can be 'sold' as having been designed with good intentions because its stated aim is to provide an opportunity for employees to improve their performance rather than to facilitate dismissal. While such a system can be viewed as a legitimate tool of managerial control, we have taken a power perspective of progressive discipline. From this perspective, we view progressive discipline as a government endorsed form of subjugation and control that can have significant detrimental effects primarily on employees which in turn may have negative consequences for employers as well. 
The paper explores some implications of the progressive discipline system as a mode of managerial power. We do this by arguing that progressive discipline is a form of managerial power, rule, and domination. In support of our argument, we present data relating to the implementation of 'progressive discipline' in Australian workplaces. The data is based on comments made by arbitrators of the Australian Industrial Relations Commission in the course of their adjudication of unfair dismissal claims brought by employees against their employers. The paper concludes by providing a model through which further research can add to an improved model of progressive discipline. The ultimate aim of the improved model would be to increase the relevance of progressive discipline as a form of managerial control in the current climate of globalisation.

\section{THE PROGRESSIVE DISCIPLINE SYSTEM}

A progressive discipline system constitutes a procedure for dealing with jobrelated behaviour of an employee who does not meet the performance standards and/or a code of proper behaviour as set by the employer. Initially, the system was implemented to make the process of dismissal fairer. This system is intended to assist an employee improve his or her work behaviour by giving him/her the necessary feedback and support to adjust to workplace requirements, rather than simply face unemployment at the whim of an employer. Employers are generally expected to give their employees an opportunity to remedy their shortcomings in performance or conduct prior to termination. Failure to do so would place employers at risk of litigation of the terminations being deemed unfair dismissals by independent labour arbitrators (Anonymous, 1999).

The word "progressive" in this form refers to incremental discipline in that penalties for misconduct get progressively harsh if the employee fails to meet the expectations of the employer. This can include failure to attend work regularly; failure to perform at levels and intensity expected; or failure to behave in accordance with the organisation's policy (Kleiner and Pesulima, 1999; Kavanaugh, and Ninemeier, 1991). According to Bernardi (1997), the disciplinary measure that is chosen should be tied to the offence rather than the employee. In this way, he says, the disciplinary measures will be more consistent and are less likely to give rise to claims of favouritism or discrimination. Scholz (2001) believes that the best way to avoid problems at the time of an employee's dismissal is to ensure that an employment contract, policy manual and progressive discipline program are in place within the organisation. Having an effective progressive disciplinary program in place contributes significantly to the 
creation of a set of conditions which promotes high levels of morale in an organisation's most valued employees as this group is attracted to, and wants to work for, a competent employer (Anderson and Pulich: 2001). While the initial goal is to obtain better performance and not to punish the employee for his/her shortcomings, we believe that the reality of progressive discipline is much more complex when we take a power perspective.

The employer's actions in carrying out the progressive discipline usually follows a four step process that consists of an oral warning, a written warning, probation, suspension, or dismissal depending on the nature of the offences and the policy of the employer (Guffey \& Helms, 2001; Kleiner \& Dhanoa, 1998; Howell,1998). If there is no progress after the employee has been given a reasonable opportunity to improve his/her conduct or the employee fails to perform in other areas in the future then the consequences are more serious; and ultimately they lead to the termination of employment (Martin, 1990). Unlike oral and written warnings, termination is not a corrective measure. Termination is used when the previous three steps have failed to help the employee to change or the offence is of a serious nature. In Australia, under section 170CG (3) of the Workplace Relations Act, 1996 (Cth), a termination is fair only if there is a valid reason or just cause for dismissal. Generally, section 170CG (3)(d) may be breached if the employee has not been warned and given time to improve; and if the employee was not given appropriate training. This legislation was amended in 2005 (Workplace Relations Amendment [WorkChoices] Act 2005) but these provisions are unchanged (Baird, Ellem and Page, 2006). Counselling and warnings must be provided to employees who are under-performing or not behaving in accordance with employers rules (James v. Waltham Cross Urban District Council, 1973 cited in McGlyne, 1979).

There is a level of irony in that progressive discipline was first established in the United States of America in the 1930s in response to the trade unions' request that employers eliminate summary terminations and develop a progressive system of punishment. It was envisaged that this process would provide a worker with protection against losing his/her job without first being fully aware that his/her job was at risk (Guffey \& Helms, 2001). The National Labor Relations Act (NLRA) of 1935 was introduced requiring that 'just cause' clauses be written into collective bargaining agreements (Guffey \& Helms, 2001). Since the 1930s, both public and private organisations in the U.S.A. have settled on a common system for handling progressive discipline (Grote, 2001). This practice has since become prevalent in the rest of the Western world, in a range of professions including nurses and doctors (White and 
Scott, 1984), academics (Palfreyman, 2005), public servants (Coleman-Seldon, 2006), and hospitality employees (Sommerville, 2007; Kavanaugh and Ninemeier, 1991).

While the progressive discipline system is often portrayed as being in the employees' best interests, framing progressive discipline through a power lens paints a very different picture. The employer is in a better position to defend termination of an employee if appropriate counselling and warnings have been provided and properly documented. Arbitrators place a great deal of importance on the notion of procedural fairness (Wilcox, 1997). Provision of counselling and warnings to the underperforming employee is normally considered in the employer's favour as meeting the requirements of procedural fairness (McPhail v. Gibson, 1977 cited in McGlyne, 1979).

It is in the above context that progressive discipline becomes relevant to both employers and employees under Australian federal legislation. Critiques of this system and recommendations for its improvement have been published in the relevant literature. Examples of criticism (Guffey and Helms, 2001; Scholz, 2001; Falcone, 2000; Lunny, 2000; Bernardi, 1997) are:

- Management may feel as if they are obligated to address every performance flaw and assign an appropriate punishment to meet the offense.

- Management may focus solely on the problem employees at the expense of the good performers in the group.

- Monitoring and disciplining problem employees may consume too much of a manager's time, not allowing the opportunity to focus on other duties.

- Progressive discipline focuses on employees' past mistakes. No emphasis is placed on helping the employee to recommit to proper performance.

- Progressive discipline may encourage adversarial relations between a manager and an employee.

- The traditional discipline system may treat the employee as a child rather than as an adult who must take the initiative and responsibility to improve his or her performance.

- Progressive discipline may create managerial resistance to perform the disciplinarian role. In turn, managers may tolerate poor performance rather than assume an adversarial role, thus complicating the discipline process.

However, there is a clear lack of literature that frames the issue overtly from a power perspective. We believe that it is time to reconsider the progressive discipline system from a power perspective. In our view, this requirement stems from the fact that the system itself draws upon some controversial assumptions about power 
relations at work and contains some problematic elements in context of contemporary employment relations. We shall briefly specify some of them here.

\section{THE RECIPROCITY OF POWER}

In the proceeding discussion, we argue that an unequal power balance exists between employee and employer in the progressive discipline system because progressive discipline follows the traditional 'power over' model. As such, the existence of progressive discipline as a method to resist the unequal power balance in favour of the employee is met with counter-resistance from managers and employers. The existence of power in organisations is ubiquitous and in many respects necessary: "Power is to organization as oxygen is to breathing" (Clegg, Courpasson and Philips, 2006). Some participants in organisations (i.e., super-ordinates) have the power to induce compliance on other participants (i.e., subordinates). In this sense, power in organisations is always unevenly distributed. This state of affairs stems from structural dependence relations which are inherent in organisations. It is 'structural' in the sense that it contains imbalanced power-dependence between two or more positions, regardless of their incumbents, in the organisation. A supervisor has more power over his or her subordinate, since the supervisor (whoever he/she is) possesses resources with which the subordinate (whoever he/she is), desires to be rewarded.

The concept of power in social life has been defined in several ways in the literature (Samuel, 2005; Clegg, 2006). Social scientists distinguish between two major kinds of power: 'power to' (in the sense of the capacity to pursue and accomplish collective goals), and 'power over' (in the sense of one's ability to control another's behaviour). 'Power to' refers to the macro level of societal affairs, whereas 'power over' refers to the micro level of interpersonal relationships (Clegg, Kornberger and Pitsis, 2008). Accordingly, 'power over' in the present sense means control over rewards and/or penalties that give one actor, A, the capacity to induce otherwise unwilling compliance by a second actor, B" (Samuel \& Zeldeitch, 1989) Thus, the manifestation of 'power over' can be seen in any kind of change in behaviour of one actor caused by another actor. From this viewpoint, power is reciprocal in that an employee acts and the employer reacts which in turn causes the employee to respond and the cycle continues until one party has achieved his or her aims. The power play here involves each actor attempting to maintain power over the other.

If one were to accept our argument that employers maintain their power over employees by hijacking progressive discipline, then is there any way of maintaining progressing discipline so that it also benefits the employee? We believe that there is a 
need to reconstruct progressive discipline so that the power imbalance is rectified. Such a reconstruction, in our view, should take place through consultative processes between all parties involved. One way forward is to rethink progressive discipline from a power perspective, where power is conceived as 'power-with' or power sharing rather than 'power-over' (Clegg, Kornberger and Pitsis, 2008; Follett, 1941). It is to this point we now turn our attention.

In its original form progressive discipline may be perceived as a form of resistance to managerial imperative, control and punishment over employees who are believed to be 'trouble makers' or unsuitable. However, where we find resistance to managerial control, there is always counter resistance by management (Putnam et al., 2005; Meyerson and Martin, 1987). In other words, management will find ways to transform the mode of power resistance to ensure it maintains their power over others. In this way progressive discipline, a tool originally designed to protect workers, is used in a way so as to legitimise punishment of behaviour which is perceived as challenging managerial control. Besides the ethical issues involved in the use of such industrial relations and human resource management tools as an overt form of punishment (Alder et al., 2007), we believe that using such tools, in the course of progressive discipline, will add to employee anxiety and dissatisfaction with work.

In reality, as a system of reciprocity, power is complex because it is more than simply A getting B to do what he or she might not necessarily want to (Clegg at al, 2008), as is the case with progressive discipline. Power can also be wilful subjugation in that a person may act in a subordinated way because he or she benefits from that subordinated relationships (Clegg et al., 2002). As such most people subjugate themselves to the will of others in at least one context - be it sticking to the speed limit to avoid a fine, queuing at a government office to pay a fine for not sticking to the speed limit, reviewing a paper even when we have little time, following the systems and processes required for promotion, a CEO adhering to the wishes of shareholders even though she is against the idea, and so on. Indeed, society functions through such wilful subjugation that occurs through governmentality. In our model of progressive discipline as a mode of punishment, we place the concept of governmentality as central.

Governmentality refers to the soft systems and structures in place that encourage people to follow in order to achieve their own needs and wants (Clegg at al 2002; Pitsis et al., 2003; 2004). In psychology, such governmental issues are evident in the topic of intrinsic motivation in which the internal drivers, desires and hopes of the individual are facilitated through appropriate work design, organisation structures, 
culture, processes, policies and practices (Clegg at al 2007). We argue that progressive discipline is currently an overt form of power over people in the traditional sense of $\mathrm{A}$ getting $\mathrm{B}$ to do something. In this sense, it is non-wilful subjugation to managerial prerogatives and imperatives. The employer holds all the power. The employee subjugates himself or herself only to the extent that if they fail to do so they face further punishment. In this sense, progressive discipline is a simplistic extrinsic form of motivation in that inappropriate behavior will be punished, appropriate behaviour will be unpunished. We believe that as a simplistic form of overt extrinsic form of power, progressive discipline will not be in the employees' interest, and will fail as an effective form of employee control.

Our intention is to present a model of progressive discipline from a power perspective that emphasises the need for progressive discipline as governmentality. Progressive discipline will have positive or beneficial outcomes for both employee and employer when the employee can see how each progressive step in the disciplinary process helps the employee improve through training and education. In other words, as a governmental tool, progressive discipline will work if it is incorporated as a process of fostering excellence and self-improvement through positive reinforcement, rather than as a form of punishment used as negative reinforcement.

\section{PROGRESSIVE DISCIPLINE AND ITS UNDERLYING ASSUMPTIONS}

A recent study (Chelliah and D'Netto, 2006) that specifically examined the variables associated with the arbitrators' awards in Australia, found that failure to apply progressive discipline and improper promulgation of work rules on the employer's part significantly increase the chances of arbitration awards favouring the employee. This study also found that other variables related to employees, that are 'culpability', 'dishonesty', and length of service also affected the outcomes of arbitrators' decisions significantly. Culpability (the extent to which the employee was responsible for the performance issue/misconduct) and dishonesty offences tended to sway arbitration decisions in the favour of employers. Interestingly, this study found that arbitrators expect employers to put in greater effort in disciplining employees with long service. Where employees were successful in their claim for unfair dismissals, the study found that long serving employees can expect their length of service to be taken into consideration in the calculation of compensation by arbitrators when reinstatement is not considered an appropriate remedy. 
As already established, progressive discipline presupposes that employers have prerogative 'power over' their employees. Presumably, this power exists because employees are dependent on employers for a regular income. Progressive discipline allows the employer to exercise power over the employee, so as to enforce compliance on to the latter, mainly due to his/her fear of the penalties specified in that procedure. Thus, the progressive discipline intimidates employees by means of potential penalties, however "progressive” they may be. Another assumption, which is implied by the progressive discipline, maintains that supervisors are qualified to appraise their subordinates' deficiencies (e.g., lack of proficiency), their improper habits (e.g., addictions) and their personality weaknesses (e.g., laziness). Accordingly, a supervisor has the right (in fact, the power, in this case) to decide the extent to which a subordinate has been showing improved conduct as expected of him or her. It is a well-known fact that a significant number of performance appraisals written by supervisors lack credibility (Kavanagh et al., 2007; Isaac, 2001). This shortcoming arises from the supervisors' lack of competence in objectively reviewing their subordinates' performance or, in some cases, their unwillingness to underrate the conduct and performance of their direct subordinates (Turnipseed and Rassuli, 2005; Chelliah and D’Netto, 2006). Due to advances in technology and global competition, employees are expected to do more in ever-decreasing time spans and senior employees work longer hours than the official contracted hours just to meet everincreasing employer demands. In the last decade, the work hours of both managerial and non-managerial occupations have steadily increased exacerbated by higher work effort requirements, stress on the job, increase in the pace of the job, and lower job and work/family balance satisfaction (ACIRRT, 1999). Furthermore, employers have had no hesitation in recent times to shed staff quickly in the name of flexibility, efficiency, and corporate restructuring regardless of loyalty, length of service or past contribution of staff (ACIRRT, 1999). Progressive discipline also implies that the employer (in practice a manager) has the right to set the appropriate performance standards for various jobs and tasks. Progressive discipline does not require the employer to reach consensus with the employee on acceptable performance standards. Although in the name of procedural fairness, employers may offer employees an opportunity to put forth their views, there is no compulsion on the employer to accept employees' views when implementing progressive discipline. These employer actions affect the morale of employees, which in turn affects the performance of employees at work. Additionally, employees may be struggling to meet the increasing or even unreasonable demands of employers. These employees may find themselves being 
subjected to employers' disciplinary processes for failing to meet employers' unreasonable expectations.

Managers are increasingly responsible for fostering a culture of overwork with very little regard for employees work-life balance (Petre, 1998). During times of economic recession, massive layoffs and greater unemployment are the order of the day. This gives employers greater justification to increase pressure on employees to work more hours and to do more tasks under the banner of 'increasing productivity/efficiency'. The progressive discipline can reinforce the inequality of power in the employment relationship in this environment often legitimised with legislative support.

Such pressures may trigger employees to play 'political games' with their supervisors such as the use of disinformation, quota restrictions, and other manipulations. The setting of performance standards and the assessing of their fulfilment by the employers without the consent of the employees (or their unions) is likely to become an ongoing conflict. This conflict could be overt or covert at the workplace. Thus, the built-in conflict in labour relations can affect the interpersonal relationships between supervisors and subordinates. By virtue of its structural nature, the power-dependence relationship described above can sometimes turn into a personal power struggle between the supervisor and employee.

Finally, progressive discipline does not seem to distinguish between misconduct and unsatisfactory job performance. The first term refers to various patterns of conduct considered illegal, immoral, or unethical in a given cultural framework. These include consuming alcoholic beverages and/or addictive drugs at work, acts of violence towards supervisors or fellow workers, sexual harassment of other employees, and theft or sabotage of the employer's property (Meggiorin, 1997). Such improper conduct is by no means comparable to inadequate performance. Obviously, employers do not have to tolerate employees' misconduct in the workplace. However, we have to keep in mind that misconduct and poor performance are essentially dissimilar and deserve different management responses. An employee whose job performance is not satisfactory in the eyes of his or her supervisor should not be regarded as a dangerous or scandalous employee. Logically this means that a poorly performing employee cannot be "disciplined" in the same way as a misbehaving employee, progressively or otherwise.

Progressive discipline has significant limitations when applied to contemporary workplaces. It relies on an outmoded model initially designed seventy-five over years ago. Today, conditions of work, the quality of employees and the characteristics of the 
labour market in Western societies are substantially different from what they were at the time of its inception. Presumably, it would be an improvement in some developing countries where the working conditions of manual workers are similar to those prevalent in the days of the Industrial Revolution in the West.

\section{DATA COLLECTION}

The data were obtained from a large study of unfair dismissals under the former Australian Workplace Relations Act 1996 (Cth) conducted by the first author of this paper. This legislation has since been amended by the Workplace Relations Amendment (Work Choices) Act 2005 (Baird, Ellem and Page, 2006). There are no changes in the amended legislation with regard to the employers' obligation to give employees notification of unsatisfactory performance prior to pursuing the course of dismissal. Data for empirical analysis was collected from unfair dismissal case decisions rendered by the AIRC. These cases on unfair dismissals were obtained from the on-line AustLII Databases. This site on the Internet is provided by the Australian Legal Information Institute (AustLII, 2001), Federal Government of Australia; it provides a free database of cases determined by the AIRC amongst others.

Decisions dealing with preliminary objections regarding the AIRC's jurisdiction to hear the case or extension of time applications were excluded from the study. Such jurisdictional issues include disputes questioning whether complainants met the eligibility requirements of the statutory protection. There were altogether 684 arbitration decisions available for this study. Initially, this whole population of cases was grouped into different industry types in accordance with the industry classification of the Australian and New Zealand Standard Industrial Classification (ANZSIC, 2001).

The next step involved ensuring that there was a level of randomness in selecting samples of the 17 industries. With this aim, every second case listed in each industry grouping was selected for analysis. In other words, 50 per cent (342 cases) of all cases in each industry grouping were selected for analysis. During the course of that study, information by way of observations made by arbitrators on the employer's system of progressive discipline was collected. Progressive discipline was an issue in 78 out of the total of 342 cases. This paper presents findings in relation to those 78 cases involving progressive discipline. 


\section{KEY FINDINGS ON PROGRESSIVE DISCIPLINE}

Table 1 shows the distribution of cases involving progressive discipline incorporating warnings by employee occupational type. Skilled workers are by far the largest group subjected to discipline. Of the total of 78 cases, nearly $45 \%$ or 35 cases belong to this group. The other significant profession is 'Sales' which is about 21\% (16 cases) of the total. On the other hand, knowledge workers such as 'Administration and Managerial' and 'Professional/Technical' comprise only 4\% (3 cases) and 6\% (5 cases) respectively. These data imply that the progressive discipline is mainly applied to employees in the lower occupational classes such as unskilled, skilled, and sales. Further, these data support our argument that the power of supervisors is exerted largely over the weaker occupational groups of the labour force.

Table 1 Occupation ( $\mathrm{n}=78$ cases)

\begin{tabular}{lcc}
\hline Employee's Occupation type & Frequency & $\%$ \\
\hline administration/managerial & 3 & 3.9 \\
\hline clerical & 9 & 11.5 \\
\hline professional/technical & 5 & 6.4 \\
\hline sales & 16 & 20.5 \\
\hline skilled & 35 & 44.9 \\
\hline unskilled & 10 & 12.8 \\
\hline total & 78 & 100 \\
\hline
\end{tabular}

Table 2 shows the distribution of the 78 discipline cases within the different industries to which employers belonged. Manufacturing, Mining, Property and Business Services, and Retail had double-digit percentages, accounting for about $53 \%$ (41 cases) of the discipline cases jointly. It might be worth mentioning that about 49 $\%$ (167 cases) of the cases selected for the main study (unfair dismissals) were in fact located in those four industries (i.e., Manufacturing, Mining, Property and Business Services, and Retail). Therefore, it comes as no surprise that the majority of disciplined cases came from these industries as well. These are in traditional industries that heavily rely on the power of management rather than on mutual cooperation. The fact that of all industries the highest proportion of the discipline cases were located in manufacturing (i.e., about 18\%) strongly supports this argument. 
Table 2 Industry Classification ( $\mathrm{n}=78$ cases)

\begin{tabular}{lcc}
\hline Industry & Frequency & $\%$ \\
\hline Accommodation \& Restaurants & 6 & 7.7 \\
\hline Communications & 5 & 6.4 \\
\hline Construction & 3 & 3.8 \\
\hline Culture and Recreation & 6 & 7.7 \\
\hline Education & 2 & 2.6 \\
\hline Finance \& Insurance & 2 & 2.6 \\
\hline Govt. \& Defence & 1 & 1.3 \\
\hline Health & 2 & 2.6 \\
\hline Manufacturing & 14 & 17.9 \\
\hline Mining & 8 & 10.3 \\
\hline Property \& Business Services & 11 & 14.1 \\
\hline Retail & 8 & 10.3 \\
\hline Transport \& Storage & 6 & 7.7 \\
\hline Wholesale & 4 & 5.1 \\
\hline Total & 78 & $100 \%$ \\
\hline
\end{tabular}

Table 3 displays the variety of offences for which employees were disciplined. Essentially, these offences can be grouped into two major categories; that is, misconduct related offences and unsatisfactory job performance. The highest number (nearly $62 \%$ ) is related to unsatisfactory job performance. The proportion of 'unsatisfactory performance' offences is higher than any of the other type of "employee offence." Following the theme of this paper, we have to recognise that unsatisfactory job performance reflects the subjective perception of supervisors. The employee, on the other hand, has very little say in the assessment of his or her job performance. With the move of societal values from collectivism to individualism in employment contracting, this problem is further exacerbated. The organised power of the unions has been declining in recent times and the individual employees, mainly at the lower level occupational classes, are more disadvantaged today. This translates into an increase in managerial power over employees. However, this seems to be more so in industries where people have less power to negotiate. 
Table 3 Employee Offences $(n=78)$

\begin{tabular}{lcc}
\hline Type of Employee Offences & Frequency & $\%$ \\
\hline absent & 2 & 2.6 \\
\hline absent without permission & 6 & 7.7 \\
\hline alcohol/drugs/gambling & 2 & 2.6 \\
\hline attitude problems & 6 & 7.7 \\
\hline dishonest & 5 & 6.4 \\
\hline insubordination & 4 & 5.1 \\
\hline negligent & 2 & 2.6 \\
\hline other - assault on staff & 1 & 1.3 \\
\hline unsatisfactory performance & 48 & 61.5 \\
\hline breaking rules & 2 & 2.6 \\
\hline total & 78 & $100 \%$
\end{tabular}

Table 4 shows the employer's purpose behind the dispensation of progressive discipline as determined by arbitrators. It reflects the outcomes that the employers were expecting to achieve at the end of the disciplinary exercise. The figures have to be interpreted with care, because the total frequencies will not add up to the total number of discipline cases (78 cases). This is due to the fact that in most cases the employer had multiple intentions or aims to achieve by the exercise of the disciplinary procedure. For example, in a particular case, 'punishment', 'correction of behaviour' and 'deterrence to other employees' may all have been the intended purpose of the employer's disciplinary exercise. It is worthwhile noting that correction of 'employee's behaviour', 'deterrence to employee' (preventing future occurrence of offence), 'deterrence to other employees' (disciplining the employee in question also acts as deterrent to other employees in future), 'affect employee dignity/ threaten job security' (employee's personal standing in the organisation is impacted in a negative sense and/or job security is threatened), and 'bring home seriousness of misconduct' to the employee were the significant aims of employers in carrying out progressive discipline. In a minor number of cases (3 cases or 3.8\%), the employer intended to punish the employee for the alleged offence. This is not an ideal feature to have in any disciplinary system. 
Table 4 Employer's Purpose in Dispensing Progressive Discipline ( $\mathrm{n}=78$ cases)

\begin{tabular}{lcc}
\hline Employer's Purpose & Frequency & $\%$ \\
\hline punishment & 3 & 3.7 \\
\hline correction of behaviour & 73 & 92.7 \\
\hline rehabilitation - drugs, alcohol, gambling & 5 & 6.0 \\
\hline deterrence to employee & 52 & 63.4 \\
\hline deterrence to other employees & 24 & 29.3 \\
\hline affect employee dignity/ threaten job security & 44 & 53.7 \\
\hline bring home seriousness of misconduct & 55 & 67.1 \\
\hline
\end{tabular}

Note: The frequencies will not add up to a $100 \%$ in total due to the presence of multiple intentions of employer when applying progressive discipline in most cases.

As the literature review clearly demonstrates, the purpose of the system must be primarily to assist the employee to reach the performance standards required by the employer. The high proportion of cases attributed to the employers' deterring and threatening their employees reveal the fact that they exercise power over their employees to obtain the outcomes that they specifically desire. A point worthy of reminder is the fact that power was conceptualised in our literature review as the ability of one actor (the employer) to induce otherwise unwilling compliance by a second actor (employee) by means of promises and threats.

In social relations, all parties possess some power over the others, not necessarily however in equal amount or strength. Thus, employees are not void of power totally. Punishment may cause employee backlash. An example of this is where an employee does not respond to the employer's demands or, in an extreme scenario, sabotages the employer's operations prior to the employee's termination of service. This is an example of counter-power exercise in the political games between employers and employees.

\section{CONCLUSION}

The literature review shows that the current model of progressive discipline was developed in the 1930s in response to American unions' demand that companies eliminate summary terminations and develop a progressive system of penalties that would provide a worker with protection against losing his/her job without first being advised that his/her job was at risk. It is not unreasonable to question the applicability and relevance of those principles developed during the Industrial Revolution to today's work environment. 
We posit that progressive discipline is an anachronistic system that leverages off employer's power in the workplace by exploiting an employee's weaker bargaining position. Our exploratory research shows that in Australia, progressive discipline predominantly affects lower level occupational (unskilled, skilled and sales) groups engaged in mainly traditional industries (manufacturing, mining, retail, etc.) which have been hotbeds of industrial unrest in recent history.

Knowledge workers operating in the information age are well educated and have portable skills which enable them to be highly mobile. These employees may not respond to traditional progressive discipline, especially when jobs are in abundance or the skills they possess are in short supply during boom times (for example IT skills during the dot.com boom). Outsourcing and independent contractor arrangements have become very popular in recent times and are convenient ways for employers to avoid time-consuming disciplinary processes which may arise; especially when both employer and employee are under pressure to reduce time-to-market cycle and to shorten response time to new customer demands.

The idea of progressive discipline may be one way of dealing with employee misconduct and unsatisfactory performance. However, other approaches may be more appropriate in dealing with the complexities of the employer-employee relationship in today's workplace. Work intensity has also increased in recent times. We suspect that as a result of the recent introduction of anti-union provisions in the Workplace Relations Amendment (Work Choices) Act 2005, the pressure to accept greater work intensity and deteriorating work conditions will increase for the lower occupational classes which we have highlighted in this study. Under these circumstances, we suspect that progressive discipline may become a powerful weapon of choice for employers.

If we are to continue with progressive discipline, then it should be viewed more as a governance mechanism to intrinsically motivate people towards excellence. Put simply, it would be better to design progressive discipline as a form of 'power with' rather than 'power over'. In this sense, progressive discipline must be paired with clear and mutually agreed processes in order to improve the employee's behaviour at work in a way that is balanced, relevant to the task, linked to organizational goals, and promotes the wilful subjugation of the employee to the organizational outcomes. Such an approach is critical, especially as employees become increasingly knowledgeable, skilled, and critical to organizational success. We suggest future research concentrate on the way in which progressive disciplined is designed, implemented, and reinforced in order to provide a better understanding of progressive discipline as governmental 
mechanisms that promote equitable power relations, rather than reinforcing archaic systems of power and hierarchy.

We believe that managers and HR professionals could be instrumental in formulating $\mathrm{HR}$ policies that allow skilled employees to give input in managing performance issues. This approach sees the employee as a partner who has a shared destiny in the well-being of the employer. With unskilled employees, it may be worth considering involvement of the labour unions (if they are members of a union) to assist these employees in structuring a performance plan which meets the employer's operational requirements. For these suggestions to work, the HR policies as a key instrument of governance of employee conduct must provide both "the stick and the carrot.” In other words, it must not only punish but provide motivation towards better performance.

It is our hope that this exploratory study will reveal strengths and weaknesses in the progressive discipline regime and become useful in the development of new 'power with' human resource management models to deal with a more highly educated, sophisticated and mobile workforce. Although we have used the Australian context to put forth a case for new rules of engagement in administering progressive discipline, our recommendations will apply to countries with similar labour legislation and human resource practices such as U.S.A., United Kingdom, Canada, and New Zealand.

\section{LIMITATIONS OF STUDY}

We readily acknowledge that there needs to be a more in-depth study, possibly using both qualitative and quantitative data to discover the true extent of the dynamics of employers' power play in the disciplinary process in the workplace. This paper is exceptional because it presents a critical approach to a traditional practice in employment relations that seems to be somewhat taken for granted; it takes a powerperspective for the purpose of analysing the concept of progressive discipline and its application at the workplace, focusing on its potential and actual misuse. Finally yet importantly, we hope this paper is a precursor to future studies of similar issues using the power perspective in the realm of work.

\section{REFERENCES}

AustLII Databases. (2001). Retrieved January 16, 2001, from http://www.austlii.edu.au/cases/cth/IRCommA/toc-1987.html 
Australia and New Zealand Standard Industrial Classification. (2001). Retrieved January 7, 2001, from http://www.abs.goc.au/Ausstats/abs@nst/Lookup/ NT00014E8A

ACIRRT. (1999). Australia at work. Sydney: Prentice Hall.

Alder, G. S., Schminke, M., \& Noel, T. W. (2007). The impact of individual ethics on reactions to potentially invasive HR practices. Journal of Business Ethics, 75(2), 201-215.

Anderson, P., \& Pulich, M. (2001). A positive look at progressive discipline. The Health Manager, 28(1), 1-10.

Anonymous. (1999). Avoiding legal pitfalls in the disciplinary process. Association of Management, 51(3), 81.

Baird, M., Ellem, B., \& Page, A. (2006). Human resource management: strategies and processes. Melbourne: Thomson.

Bernardi, L. M. (1997). Maximizing employee performance through progressive discipline. The Canadian Manager, 22(1), 14-17.

Chelliah, J., \& D'Netto, B. (2006). Unfair dismissals in Australia: does arbitration help employees? Employee Relations, 28(5), 483-495.

Clegg, S. R., Courpasson, D., \& Philips, N. (2006). Power and Organizations. London: Sage.

Clegg, S. R., Kornberger, M., \& Pitsis, T. S. (2008). Management and organizations: an introduction to theory and practice (2nd ed.). California: Sage.

Clegg, S. R., \& Pitsis, T. S. (2007). The art of alliancing: from imperative control to concerted coordination. In S. Ville, G. Boyce \& S. Macintyre (Eds.), How Organisations Connect: Investing in Communication. (pp. 32-53). Melbourne: Melbourne University Press.

Clegg, S. R., Pitsis, T. S., Rura-Polley, T., \& Marosszeky, M. (2002). Governmentality matters: designing an alliance culture for interorganizational collaboration. Organization Studies, 23(2), 317-337.

Coleman-Selden, S. (2006). The impact of discipline on the use and rapidity of dismissal in state governments. Review of Public Personnel Administration, 26(4), 335-355.

Falcone, P. (2000). A blueprint for progressive discipline and terminations. HR Focus, 77(8), 3-6.

Follett, M. P. (1941). Dynamic administration. In H. C. Metcalf \& L. Urwick (eds.), The Collected Papers of Mary Parker Follett. (pp. 167-183). New York: Harper \& Bros. 
Grote, D. (2001). Discipline without punishment. Across the Board, 38(5), 52-58.

Guffey, C. J., \& Helms, M. M. (2001). Effective employee discipline: a case of the Internal Revenue Service. Public Personnel Management, 30(1), 111-128.

Howell, C. (1998). Unfair dismissals under the Workplace Relations Act 1996. Alternative Law Journal, 23(2), 63-66.

Isaac, J. E. (2001). The importance of fairness. Journal of Industrial Relations, 43(2), 111-123.

James v. Waltham Cross Urban District Council (1973). ICR, 398.

Kavanagh, P., Benson, J., \& Brown, M. (2007.). Understanding performance appraisals. Asia Pacific Journal of Human Resources, 45(2), 132-150. .

Kavanaugh, R. R., \& Ninemeier, J. D. (1991). Confronting major violations: progressive discipline programs. Restaurant Personnel Management, 4(10), 1-2.

Kleiner, B., \& Pesulima, S. (1999). Management: professional update on discipline. Australian Company Secretary, 51(4), 187-189.

Kleiner, B. a., \& Dhanoa, D. (1998). How to conduct due process discipline. Australian Company Secretary, 50(11), 524-527.

Lunny, J. (2000). Flexibility and constructive dismissal tensions: forced change by employers. Employment Law Bulletin, 6(4), 29-30.

Martin, L. (1990). Discipline for professional employees. Personnel Journal, 69(12), 27-28.

McGlyne, J. E. (1979). Unfair dismissal cases (2nd ed.). London: Butterworths.

McPhail v. Gibson (1977). I.C.R. 42.

Meggiorin, H. (1997). Proving misconduct in order to justify dismissal under the Workplace Relations Act (Cth). Corporate and Business Law Journal, 12(2), 163-205.

Meyerson, D., \& Martin, J. (1987). Cultural change: an integration of three different views. Journal of Management Studies, 24(6), 623-647.

Palfreyman, D. (2005). A note on the misconduct of academics in UK HEIs. Education and the Law, 17(4), 155 - 159.

Petre, D. (1998). Father time: making time for your children. Sydney: Macmillan.

Pitsis, T. S., Kornberger, M., \& Clegg, S. R. (2004). The art of managing relationships in interorganizational collaboration. Management, 7(3), 47-67.

Pitsis, T. S., Clegg, S. R., Marosszeky, M., \& Rura-Polley, T. (2003). Constructing the Olympic dream: a future perfect strategy of project management. Organization Science, 14(5), 574-590. 
Putnam, L. L., Grant, D., Michelson, G., \& Cutcher, L. (2005). Discourse and resistance: targets, practices, and consequences. Management Communication Quarterly, 19(1), 5-19.

Samuel, Y. (2005). The Political agenda of organizations. New Brunswick: Transaction Publishers.

Samuel, Y., \& Zeldeitch, M. B. (1989). Expectations, shared awareness, and power. In J. Berger, M. Zeldtich \& B. Anderson (Eds.), Sociological Theories in Progress (pp. 288-312). California: Sage.

Scholz, K. (2001). The law of employee dismissals. The Canadian Manager, 26(4), 912.

Sommerville, K. L. (2007). Hospitality employee management and supervision: concepts and practical applications. New Jersey: John Wiley \& Sons.

Turnipseed, D. L., \& Rassuli, A. (2005). Performance perceptions of organizational citizenship behaviours at work: a bi-level study among managers and employees. British Journal of Management, 16(3), 231-244.

White, S. J., \& Scott, B. E. (1984). Progressive discipline. American Journal of Hospital Pharmacy, 41(9), 1824-1828.

Wilcox, M. (1997). Dismissal: a fair go all round? In M. Lee \& P. Sheldon (Eds.), Workplace Relations. North Ryde: Butterworths.

Workplace Relations Amendment (Work Choices) Act of 2005, No. 153 (2005).

Workplace Relations Act of 1996, No.8 (2008). 